\title{
Age-related sarcopenia and its pathophysiological bases
}

\author{
Sumito Ogawa*, Mitsutaka Yakabe and Masahiro Akishita
}

\begin{abstract}
Age-related loss of the skeletal muscle and its function is known as sarcopenia. Definition and diagnostic criteria for sarcopenia have been outlined as consensus statements from several study groups, including usual gait speed, grip strength, and skeletal muscle mass. Whereas underlying mechanisms and pathophysiology of sarcopenia remains to be clarified, recent studies have suggested that chronic inflammatory status as well as lifestyle-related factors in older individuals might contribute to the process and progress of sarcopenia.
\end{abstract}

Keywords: Aging, Sarcopenia, Inflammation, Frailty, Hormone

\section{Background}

Sarcopenia has been recently recognized as an age-related symptom which is characterized by low muscle mass, low muscle force, and low physical performance. In this review, we describe the recent progresses regarding the development of definition and diagnosis of sarcopenia, as well as its pathophysiology mainly related to agerelated inflammatory processes.

\section{Definition and diagnosis of sarcopenia}

Recent clinical and studies have suggested the presence of age-related decline in skeletal muscle mass and muscle strength from approximately the fifth decade of life, called sarcopenia [1]. This debilitating process is known to associate with frailty, disability [2], and an increased risk of fall-related fractures [3], leading to higher mortality and morbidity in the older population $[4,5]$. The number of older population with sarcopenia is expected to increase all over the world, and it is becoming one of the important public concerns and interests [6].

Sarcopenia (Greek "sarx" or flesh + "penia" or loss) was initially proposed by Rosenberg, representing agerelated loss of muscle mass in its original concept [7]. Subsequently, the European Working Group on Sarcopenia in Older People (EWGSOP) defined sarcopenia in 2010 as a syndrome characterized by progressive and generalized loss of skeletal muscle mass and strength

* Correspondence: suogawa-tky@umin.ac.jp

Department of Geriatric Medicine, Graduate School of Medicine, The University of Tokyo, Bunkyo-ku, Tokyo 113-8655, Japan with the risk of adverse outcome such as physical disability, poor quality of life, and death [8]. The impact of sarcopenia on Asian regions including Japan is also estimated to be high, and the Asian Working Group for Sarcopenia (AWGS) agreed to describe sarcopenia as low muscle mass plus low muscle strength and/or low physical performance, further recommending its assessment in healthcare settings and in clinical practice [9] (Fig. 1). Thus, current approaches to the definition of sarcopenia are based on measurements of muscle mass, muscle strength, and functional capacity, and each indicator might be considered low when it is less than two standard deviations (2SD) away from the mean value of young male and female reference groups. The EWGSOP has developed a suggested algorithm based on gait speed measurement as the easiest and most reliable way to begin sarcopenia case finding or screening in practice.

As for the screening among community-dwelling people aged 65 years and older, the EWGSOP has developed a suggested algorithm based on (i) lower skeletal muscle mass plus (ii) lower gait speed and/or low grip strength for the diagnosis of sarcopenia [8]. AWGS also recommends using 60 or 65 years as the age for sarcopenia diagnosis according to the conditions of each country in Asia [9]. Operational sarcopenia definition by the International Working Group for Sarcopenia (IWGS) was targeted to individuals with functional decline, self-reported mobility-related difficulties, history of recurrent falls, recent unintentional body weight loss, post-hospitalization, and chronic conditions including metabolic diseases and 


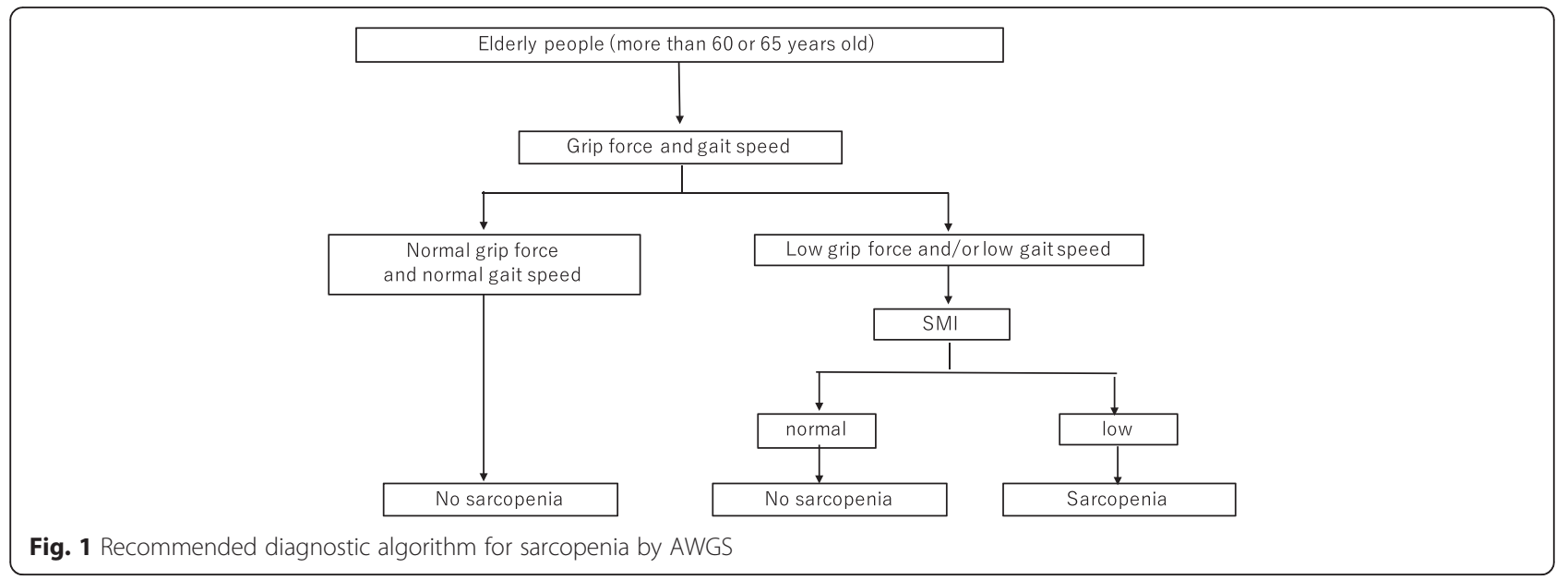

cancer [10]. The Foundation for the National Institutes of Health (FNIH) used the data from nine sources of community-dwelling older population and proposed the cutoffs based on its analysis [11]. A comparison of definition/characteristics and cutoff values for sarcopenia in EWGSOP, AWGS, and IWGS criteria is shown in Table 1 [8-10].

It is proposed by the EWGSOP that sarcopenia is considered primary (or age-related) when no other cause is evident except aging itself, whereas it is considered secondary when one or more other causes are evident [8]. In practice, the etiology of sarcopenia is multi-factorial, and it might not be always possible to identify and characterize its single cause. EWGSOP also suggests a conceptual staging as severe sarcopenia, sarcopenia, and pre-sarcopenia. Severe sarcopenia is the stage when all three criteria (low muscle mass, low muscle strength, and low physical performance) are observed. The sarcopenia stage is defined as low muscle mass, accompanying either low muscle strength or low physical performance. The pre-sarcopenia stage is characterized by low muscle mass without low muscle strength or low physical performance. Evaluation of these sarcopenia stages might be helpful in light of setting appropriate recovery goals as well as selecting treatments and intervention.
In terms of epidemiology and prevalence of sarcopenia, Baumgartner et al., adopting a skeletal muscle mass index (SMI) cutoff of $-2 \mathrm{SDs}$ below the mean of a young reference group, reported that the prevalence ranged from 13 to $24 \%$ in persons aged 65 to 70 years old and was more than $50 \%$ for those who were older than 80 years old [12]. Another study suggested that sarcopenia was prevalent in $10 \%$ of men and $8 \%$ of women older than 60 years old and that decrease in skeletal muscle was independently associated with functional impairment and disability, especially in older women [13]. The prevalence of sarcopenia in Japanese elderly men and women, based on the Asian diagnosis criteria, was 9.6 and $7.7 \%$, respectively [14]. The number of aged population over 60 years of age around the world was estimated to be 600 million in 2000 and is expected to rise to 2 billion by 2050. It is also estimated that sarcopenia will affect over 200 million people by the period, in contrast to the present estimation of about 50 million people [15].

\section{Pathophysiology of sarcopenia related to chronic inflammatory state}

It is suggested that significant changes in muscle mass and its quality are observed during aging process and that there is a decrease in muscle mass at an annual rate

Table 1 Comparison of definition/characteristics and cutoff values for sarcopenia by EWGSOP, AWGS, and IWGS criteria

\begin{tabular}{|c|c|c|c|}
\hline & EWGSOP [8] & AWGS [9] & IWGS [10] \\
\hline $\begin{array}{l}\text { Definition/ } \\
\text { characteristics }\end{array}$ & $\begin{array}{l}\text { A syndrome characterized by progressive and } \\
\text { generalized loss of skeletal muscle mass and } \\
\text { strength with a risk of adverse outcomes }\end{array}$ & $\begin{array}{l}\text { Age-related decline of skeletal muscle plus } \\
\text { low muscle strength and/or physical } \\
\text { performance }\end{array}$ & $\begin{array}{l}\text { Age-associated loss of skeletal } \\
\text { muscle mass and function }\end{array}$ \\
\hline SMI & $\begin{array}{l}7.26 \mathrm{~kg} / \mathrm{m}^{2} \text { for men and } 5.5 \mathrm{~kg} / \mathrm{m}^{2} \text { for women } \\
\text { (by DXA). } 8.87 \mathrm{~kg} / \mathrm{m}^{2} \text { for men and } 6.42 \mathrm{~kg} / \mathrm{m}^{2} \\
\text { for women (by BIA) }\end{array}$ & $\begin{array}{l}7.0 \mathrm{~kg} / \mathrm{m}^{2} \text { for men and } 5.4 \mathrm{~kg} / \mathrm{m}^{2} \text { for women } \\
\text { (by DXA). } 7.0 \mathrm{~kg} / \mathrm{m}^{2} \text { for men and } 5.7 \mathrm{~kg} / \mathrm{m}^{2} \\
\text { for women (by BIA) }\end{array}$ & $\begin{array}{l}7.23 \mathrm{~kg} / \mathrm{m}^{2} \text { for men and } 5.67 \mathrm{~kg} / \mathrm{m}^{2} \\
\text { for women (by DXA) }\end{array}$ \\
\hline Walking speed & $<0.8 \mathrm{~m} / \mathrm{s}$ & $<0.8 \mathrm{~m} / \mathrm{s}$ & $<1.0 \mathrm{~m} / \mathrm{s}$ \\
\hline Grip force & $\begin{array}{l}<30 \mathrm{~kg} \text { for men } \\
<20 \mathrm{~kg} \text { for women }\end{array}$ & $\begin{array}{l}<26 \mathrm{~kg} \text { for men } \\
<18 \mathrm{~kg} \text { for women }\end{array}$ & Not specified \\
\hline
\end{tabular}


of 1 to $2 \%$ after about 50 years old [16]. The decline in muscle strength is supposed to be more significant, reaching to $1.5 \%$ per year in their sixth decade and to $3 \%$ per year afterwards [17]. In average, age-related decreases in knee extensor strength are 20-40 \% compared to that of young adult mean [18], and more significant losses have been observed for those in their ninth decades $[19,20]$. Recent findings suggest that multiple factors including immobility, malnutrition, low protein intake, changes in hormones and metabolism, systemic inflammation, and neuromuscular aging are supposed to influence age-related sarcopenia [21, 22].

From a histological standpoint, the skeletal muscle consists of type I and type II fibers. Type II fast fibers possess a higher glycolytic potential, lower oxidative capacity, and faster response, whereas type I slow fibers are known as fatigue-resistant due to their characteristics such as greater density and content of mitochondria, capillaries, and myoglobin. And sarcopenia is characterized by the predominant atrophy of type II fibers together with smaller and fewer mitochondria [23, 24]. Although molecular and cellular mechanisms underlying sarcopenia still remain to be clarified, age-related low-grade inflammation has been suggested to be involved as described below.

In general, aging is associated with a significant rise in serum levels of inflammatory markers and its related factors [25]. Franceschi et al. described the state of chronic low-grade inflammatory state as "inflammaging" based on the related concept of immunosenescence [26, 27]. Inflammation can be beneficial as an acute, transient immune response to harmful conditions including tissue injury or pathogen invasion. During aging process, these acute inflammatory responses may be impaired, leading to increased susceptibility to infection. Inflammaging is characterized as low-grade, chronic, systemic inflammation in aging in the absence of infection, which results in responses that lead to tissue degeneration. Inflammaging is also suggested to be related to various age-related diseases represented by atherosclerosis, dementia, type 2 diabetes and osteoporosis and is a highly significant risk factor for both morbidity and mortality in the elderly people [26, 28] (Fig. 2). Inflammaging is supposed to be a consequence of a reduced immune response or lifetime exposure to antigenic stimuli $[29,30]$, leading to the production of reactive oxygen species and tissue damage with the release of cytokines mediated by innate and acquired immune system [31]. In practice, inflammaging is accompanied by age-related decline in the number of $\mathrm{T}$ and $\mathrm{B}$ cells together with an increase of natural killer cells [32], and tumor necrosis factor- $\alpha$ (TNF- $\alpha$ ), interleukin-6 (IL-6), interleukin-1 (IL-1), and $\mathrm{C}$-reactive protein (CRP) are mainly involved in this process $[27,33,34]$. These cytokines are suggested to lead to a predisposition to age-related sarcopenia subsequently through the activation of the ubiquitine-protease system $[35,36]$. And this altered activation of cellular signaling pathway is considered to promote the inflammatory state regardless of tissue damage or antigenic exposure, further contributing to one of the pathogenetic bases underlying sarcopenia [37-39]. It is also suggested that cytokines may antagonize the anabolic effect mediated by insulin growth

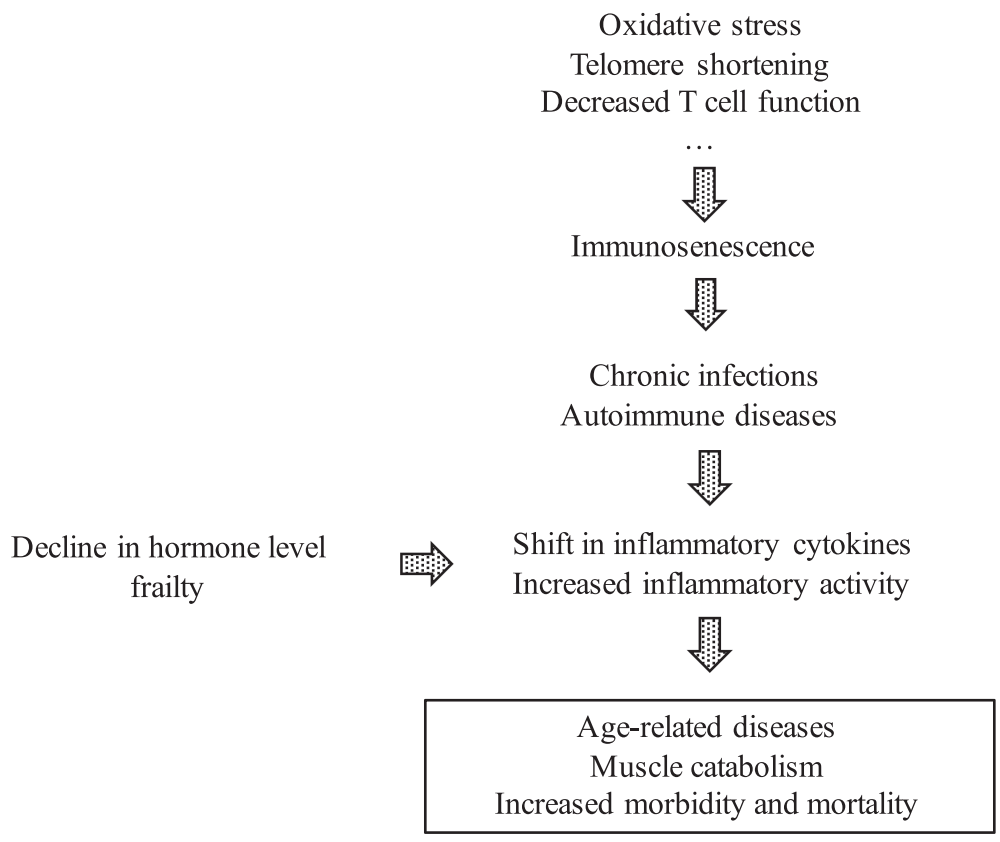

Fig. 2 Influence of potential factors leading to age-related inflammatory processes 
factor-1 (IGF-1), involving in growth hormone resistance which limit IGF-I availability [40, 41]. Inflammaging also contributes to anabolic resistance, which is one of the main determinants of sarcopenia, implying that synthesis of skeletal muscle protein in response to physiologic stimuli is below the standard of muscle maintenance in the older population [42].

\section{Possible cytokines involved in age-related sarcopenia}

Recent findings suggest that some inflammatory cytokines including TNF- $\alpha$ and IL- 6 are involved in pathophysiology of age-related sarcopenia.

\section{TNF- $a$}

Plasma TNF- $\alpha$ concentration preceded a significant decline in muscle strength at 4 years in study subjects aged 85 years [43] and in decline in muscle mass and its strength at 5 years in subjects aged 70 to 79 years at baseline [44]. Exposure of myoblasts to TNF- $\alpha$ causes inhibition of myogenic differentiation through increased proteolysis of MyoD by the ubiquitin-proteasome pathway in vitro [45]. TNF- $\alpha$ is also reported to suppress the Akt/mTOR pathway [41], promoting muscle catabolism, oxidative stress, and nitric acid production [46, 47]. Decrease of TNF- $\alpha$ level mediated by muscle training, for example, is suggested to cause muscle regeneration [48-50].

\section{IL-6}

Some clinical studies including a longitudinal study in the Netherlands reported that high levels of IL- 6 and CRP are associated with lower physical performance, muscle strength, and muscle mass $[38,50-58]$. In a 6-year cohort of community-dwelling elderly subjects, elevated serum concentrations of IL- 6 and IL-1RA have been associated with decline in physical performance [58]. Hospitalized geriatric patients with inflammation represented significantly weaker muscle function, shoulder extension strength, and a worse fatigue resistance [59]. In a cross-sectional study carried out in community-dwelling women aged more than 65 years, serum IL-6 levels were associated with higher prevalence of frailty [60]. In older women, higher serum IL-6 levels were adversely associated with recovery of lower extremity function after hip fracture [61].

In an experimental study, IL-6 transgenic mice revealed decreased skeletal muscle mass, and anti-mouse IL-6R antibody inhibited the atrophy [62]. Another study suggested that IL- 6 and serum amyloid A produced in the liver synergistically increased MuRF1 and atrogin-1 expression by inducing SOCS-3 expression and impairing its downstream insulin/IGF-1 signaling in the skeletal muscle [63]. On the other hand, IL-6 is a pleiotropic cytokine, acting both as an inflammatory cytokine and as a myokine. For example, acute exercise causes skeletal muscle contraction and promotes IL- 6 release into the systemic circulation, which could be beneficial for muscle growth [64]. Further studies are needed to elucidate how IL-6 are involved in the pathogenesis of age-related sarcopenia.

\section{Other cytokines and inflammatory substrates}

A recent study suggested that IL-1 blocked differentiation of human myoblasts into myotubes by activating TGF- $\beta$-activated kinase (TAK)- 1 in vitro [65] and might be involved in sarcopenia. In addition, several clinical studies imply the relationship between serum CRP concentration and sarcopenia. For example, high-sensitivity CRP levels were significantly associated with sarcopenic obesity in a Korean study [66]. Proinflammatory cytokines, such as IL- 6 and TNF- $\alpha$, induce the production of CRP in the liver, and it has not been clarified whether high CRP level directly affects sarcopenia.

\section{Conclusions}

Age-related sarcopenia is a phenomenon that results in significant mortality as well as morbidity in the older population and is becoming one of the major public health problems among aging society. Emerging evidences suggest underlying mechanisms and pathophysiology of age-related sarcopenia, in which the relationship between chronic inflammatory state, muscle strength, and muscle mass seems to possess a pathogenetic basis including the control of balance between protein synthesis and its catabolism. In terms of inflammaging, age-related changes in cytokines and hormones levels are also suggested to be important risk factors for muscular impairment. A better understanding and knowledge of risk factors for sarcopenia is important to promote multidimensional approach based on its pathophysiology, defining molecular targets for intervention toward successful prevention and treatment in the near future.

\section{Abbreviations \\ CRP, C-reactive protein; IGF-1, insulin growth factor-1; IL-1, interleukin-1; IL-6, interleukin-6; SMI, skeletal muscle mass index; TNF, tumor necrosis factor}

\author{
Acknowledgements \\ The authors thank $\mathrm{H}$. Sasagawa for the cooperation and help for the \\ manuscript preparation. \\ Funding \\ This study was supported by the Research Funding for Longevity Sciences \\ from the National Center for Geriatrics and Gerontology (NCGG), Japan. This \\ work was also supported by JSPS KAKENHI Grant Number 15K08898. The \\ funders had no role in the study design, data collection and analysis, \\ decision to publish, or preparation of the manuscript.
}

Availability of data and materials Not applicable. 


\section{Authors' contributions}

SO and MY drafted the review manuscript, and SO and MA conceived of the study and participated in its coordination. MA contributed to the writing of the manuscript. All authors read and approved the final manuscript.

\section{Authors' information}

None.

\section{Competing interests}

The authors declare that they have no competing interests.

\section{Consent for publication}

Not applicable.

\section{Ethics approval and consent to participate}

Not applicable.

Received: 5 May 2016 Accepted: 6 July 2016

Published: 7 September 2016

\section{References}

1. Janssen I, Heymsfield SB, Wang ZM, Ross R. Skeletal muscle mass and distribution in 468 men and women aged 18-88 years. J Appl Physiol. 2000:89:81-8.

2. Morley JE. Sarcopenia in the elderly. Fam Pract. 2012;29 Suppl 1:144-8.

3. Visser M, Schaap LA. Consequences of sarcopenia. Clin Geriatric Med. 2011;27:387-99.

4. Kemmler W, von Stengel S, Engelke K, Haberle L, Mayhew JL, Kalender WA Exercise, body composition, and functional ability: a randomized controlled trial. Am J Prev Med. 2010;38:279-87.

5. Bunout D, de la Maza MP, Barrera G, Leiva L, Hirsch S. Association between sarcopenia and mortality in healthy older people. Australas J Ageing. 2011:30:89-92.

6. Kim TN, Choi KM. Sarcopenia: definition, epidemiology, and pathophysiology. J Bone Metab. 2013:20:1-10

7. Rosenberg IH. Sarcopenia: origins and clinical relevance. J Nutr. 1997;127:990S-1.

8. Cruz-Jentoft AJ, Baeyens JP, Bauer JM, Boirie Y, Cederholm T, Landi F, Martin FC, Michel JP, Rolland Y, Schneider SM, Topinkova E, Vandewoude M, Zamboni M. Sarcopenia: European consensus on definition and diagnosis: Report of the European Working Group on Sarcopenia in Older People. Age Ageing. 2010;39:412-23.

9. Chen LK, Liu LK, Woo J, Assantachai P, Auyeung TW, Bahyah KS, Chou MY, Chen LY, Hsu PS, Krairit O, Lee JS, Lee WJ, Lee Y, Liang CK, Limpawattana P, Lin CS, Peng LN, Satake S, Suzuki T, Won CW, Wu CH, Wu SN, Zhang T, Zeng P, Akishita M, Arai H. Sarcopenia in Asia: consensus report of the Asian Working Group for Sarcopenia. J Am Med Dir Assoc. 2014;15:95-101.

10. Fielding RA, Vellas B, Evans WJ, Bhasin S, Morley JE, Newman AB, Abellan van Kan G, Andrieu S, Bauer J, Breuille D, Cederholm T, Chandler J, De Meynard C, Donini L, Harris T, Kannt A, Keime Guibert F, Onder G, Papanicolaou D, Rolland Y, Rooks D, Sieber C, Souhami E, Verlaan S, Zamboni M. Sarcopenia: an undiagnosed condition in older adults. Current consensus definition: prevalence, etiology, and consequences. International Working Group on Sarcopenia. J Am Med Dir Assoc. 2011;12:249-56.

11. Studenski SA, Peters KW, Alley DE, Cawthon PM, McLean RR, Harris TB, Ferrucci L, Guralnik JM, Fragala MS, Kenny AM, Kiel DP, Kritchevsky SB, Shardell MD, Dam TT, Vassileva MT. The FNIH sarcopenia project: rationale, study description, conference recommendations, and final estimates. J Gerontol A Biol Sci Med Sci. 2014;69:547-58.

12. Baumgartner RN, Koehler KM, Gallagher D, Romero L, Heymsfield SB, Ross RR, Garry PJ, Lindeman RD. Epidemiology of sarcopenia among the elderly in New Mexico. Am J Epidemiol. 1998;147:755-63.

13. Janssen I, Heymsfield SB, Ross R. Low relative skeletal muscle mass (sarcopenia) in older persons is associated with functional impairment and physical disability. J Am Geriatr Soc. 2002;50:889-96.

14. Yuki A, Ando F, Shimokata H. Transdisciplinary approach for sarcopenia. Sarcopenia: definition and the criteria for Asian elderly people. Clin Calcium. 2014;24:1441-8.

15. Santilli V, Bernetti A, Mangone M, Paoloni M. Clinical definition of sarcopenia. Clin Cases Miner Bone Metab. 2014;11:177-80.
16. Sehl ME, Yates FE. Kinetics of human aging: I. Rates of senescence between ages 30 and 70 years in healthy people. J Gerontol A Biol Sci Med Sci. 2001;56:198-208.

17. von Haehling S, Morley JE, Anker SD. An overview of sarcopenia: facts and numbers on prevalence and clinical impact. J Cachexia Sarcopenia Muscle. 2010;1:129-33.

18. Doherty TJ. Invited review: aging and sarcopenia. J Appl Physiol. 2003;95:1717-27.

19. Murray MP, Duthie Jr EH, Gambert SR, Sepic SB, Mollinger LA. Age-related differences in knee muscle strength in normal women. J Gerontol. 1985; $40: 275-80$

20. Murray MP, Gardner GM, Mollinger LA, Sepic SB. Strength of isometric and isokinetic contractions: knee muscles of men aged 20 to 86 . Phys Ther. 1980:60:412-9.

21. Malafarina V, Uriz-Otano F, Iniesta R, Gil-Guerrero L. Sarcopenia in the elderly: diagnosis, physiopathology and treatment. Maturitas. 2012;71:109-14.

22. Yakabe M, Ogawa S, Akishita M. Clinical manifestations and pathophysiology of sarcopenia. RNA and Transcription. 2015;1:10-7.

23. Lang T, Streeper T, Cawthon P, Baldwin K, Taaffe DR, Harris TB. Sarcopenia: etiology, clinical consequences, intervention and assessment. Osteoporosis Int. 2010;21:543-59.

24. Evans WJ, Campbell WW. Sarcopenia and age-related changes in body composition and functional capacity. J Nutr. 1993;123:465-8.

25. Ferrucci L, Corsi A, Lauretani F, Bandinelli S, Bartali B, Taub DD, Guralnik JM, Longo DL. The origins of age-related proinflammatory state. Blood. 2005; 105:2294-9.

26. Franceschi C, Bonafe M, Valensin S, Olivieri F, De Luca M, Ottaviani E, De Benedictis $\mathrm{G}$. Inflamm-aging. An evolutionary perspective on immunosenescence. Ann N Y Acad Sci. 2000;908:244-54.

27. Franceschi C, Campisi J. Chronic inflammation (inflammaging) and its potential contribution to age-associated diseases. J Gerontol A Biol Sci Med Sci. 2014;69:54-9.

28. Castelo-Branco C, Soveral I. The immune system and aging: a review. Gynecol Endocrinol. 2014;30:16-22.

29. De Martinis M, Franceschi C, Monti D, Ginaldi L. Inflammageing and lifelong antigenic load as major determinants of ageing rate and longevity. FEBS Lett. 2005:579:2035-9.

30. Frasca $\mathrm{D}$, Blomberg BB. Inflammaging decreases adaptive and innate immune responses in mice and humans. Biogerontology. 2016:17:7-19.

31. Cannizzo ES, Clement CC, Sahu R, Follo C, Santambrogio L. Oxidative stress, inflamm-aging and immunosenescence. J Proteomics. 2011;74:2313-23.

32. Sansoni P, Vescovini R, Fagnoni F, Biasini C, Zanni F, Zanlari L, Telera A, Lucchini G, Passeri G, Monti D, Franceschi C, Passeri M. The immune system in extreme longevity. Exp Gerontol. 2008:43:61-5.

33. Maggio M, Guralnik JM, Longo DL, Ferrucci L. Interleukin-6 in aging and chronic disease: a magnificent pathway. J Gerontol A Biol Sci Med Sci. 2006;6:575-84.

34. Thomas DR. Sarcopenia. Clin Geriatr Med. 2010;26:331-46.

35. Mitch WE, Goldberg AL. Mechanisms of muscle wasting. The role of the ubiquitin-proteasome pathway. N Eng J Med. 1996;335:1897-905.

36. Ferrucci L, Harris TB, Guralnik JM, Tracy RP, Corti MC, Cohen HJ, Penninx B, Pahor M, Wallace R, Havlik RJ. Serum IL-6 level and the development of disability in older persons. J Am Geriatr Soc. 1999;47:639-46.

37. Toth MJ, Ades PA, Tischler MD, Tracy RP, LeWinter MM. Immune activation is associated with reduced skeletal muscle mass and physical function in chronic heart failure. Int J Cardiol. 2006;109:179-87.

38. Visser M, Pahor M, Taaffe DR, Goodpaster BH, Simonsick EM, Newman AB, Nevitt M, Harris TB. Relationship of interleukin- 6 and tumor necrosis factoralpha with muscle mass and muscle strength in elderly men and women: the Health ABC study. J Gerontol. 2002;57A:M326-32.

39. Curtis E, Litwic A, Cooper C, Dennison E. Determinants of muscle and bone aging. J Cell Physiol. 2015;230:2618-25.

40. Lang $\mathrm{CH}$, Frost RA, Vary TC. Regulation of muscle protein synthesis during sepsis and inflammation. Am J Physiol Endocrinol Metab. 2007;293:e453-9.

41. Frost RA, Lang $\mathrm{CH}$. Protein kinase B/Akt: a nexus of growth factor and cytokine signalling determining muscle mass. J Appl Physiol. 2007;103:378-87.

42. Haran PH, Rivas DA, Fielding RA. Role and potential mechanisms of anabolic resistance in sarcopenia. J Cachexia Sarcopenia Muscle. 2012:3:157-62

43. Taekema DG, Westendorp RG, Frölich M, Gussekloo J. High innate production capacity of tumor necrosis factor-alpha and decline of handgrip strength in old age. Mech Ageing Dev. 2007;128:517-21.

44. Schaap LA, Pluijm SM, Deeg DJ, Harris TB, Kritchevsky SB, Newman AB, Colbert LH, Pahor M, Rubin SM, Tylavsky FA, Visser M, Health ABC Study. 
Higher inflammatory marker levels in older persons: associations with 5-year change in muscle mass and muscle strength. J Gerontol A Biol Sci Med Sci. 2009;64:1183-9.

45. Langen RC, Van Der Velden JL, Schols AM, Kelders MC, Wouters EF, JanssenHeininger YM. Tumor necrosis factor-alpha inhibits myogenic differentiation through MyoD protein destabilization. FASEB J. 2004;18:227-37.

46. Reid MB, Li YP. Tumor necrosis factor-alpha and muscle wasting: a cellular perspective. Respir Res. 2001;2:269-72.

47. Reid MB, Lännergren J, Westerblad H. Respiratory and limb muscle weakness induced by tumor necrosis factor-alpha: involvement of muscle myofilaments. Am J Respir Crit Care Med. 2002;166:479-84.

48. Mourkioti F, Kratsios P, Luedde T, Song YH, Delafontaine P, Adami R, Parente V, Bottinelli R, Pasparakis M, Rosenthal N. Targeted ablation of IKK2 improves skeletal muscle strength, maintains mass, and promotes regeneration. J Clin Invest. 2006:116:2945-54.

49. Starkie R, Ostrowski SR, Jauffred S, Febbraio M, Pedersen BK. Exercise and IL-6 infusion inhibit endotoxin-induced TNF-alpha production in humans. FASEB J. 2003;17:884-6.

50. Greiwe JS, Cheng B, Rubin DC, Yarasheski KE, Semenkovich CF. Resistance exercise decreases skeletal muscle tumor necrosis factor alpha in frail elderly humans. FASEB J. 2001;15:475-82

51. Schaap L, Pluijim SMF, Deeg DJH, Visser M. Inflammatory markers and loss of muscle mass (sarcopenia) and strength. Am J Med. 2006;119:526. e9-526.e17.

52. Cesari M, Penninx BW, Pahor M, Lauretani F, Corsi AM, Rhys Williams G, Guralnik JM, Ferrucci L. Inflammatory markers and physical performance in older persons: the InCHIANTI study. J Gerontol A Biol Sci Med Sci. 2004;59:242-8.

53. Schaap LA, Pluijm SM, Deeg DJ, Harris TB, Kritchevsky SB, Newman AB, Colbert LH, Pahor M, Rubin SM, Tylavsky FA, Visser M, Health ABC Study. Higher inflammatory markers levels in older persons: association with 5-year change in muscle mass and strength. J Gerontol A Bio Sci Med Sci. 2009;64A:1183-9.

54. Pedersen M, Bruunsgaard $H$, Weis $N$, Hendel HW, Andreassen BU, Eldrup $E_{1}$ Dela F, Pedersen BK. Circulating levels of TNF-alpha and IL-6-relation to truncal fat mass and muscle mass in healthy elderly individuals and in patients with type-2 diabetes. Mech Ageing Dev. 2003;124:495-502.

55. Barbieri M, Ferrucci L, Ragno E, Corsi A, Bandinelli S, Bonafè M, Olivieri F, Giovagnetti S, Franceschi C, Guralnik JM, Paolisso G. Chronic inflammation and the effect of IGF-I on muscle strength and power in older persons. Am J Physiol Endocrinol Metab. 2003;284:E481-7.

56. Norman K, Stobaus N, Kulka K, Schulzke J. Effect of inflammation on handgrip strength in the non-critically ill is independent from age, gender and body composition. European J Clin Nutrition. 2014;68:155-8.

57. Ferrucci L, Penninx BW, Volpato S, Harris TB, Bandeen-Roche K, Balfour J, Leveille SG, Fried LP, Md JM. Change in muscle strength explains accelerated decline of physical function in older women with high interleukin-6 serum levels. J Am Geriatr Soc. 2002;50:1947-54.

58. Stenholm S, Maggio M, Lauretani F, Bandinelli S, Ceda GP, Di lorio A, Giallauria F, Guralnik JM, Ferrucci L. Anabolic and catabolic biomarkers as predictors of muscle strength decline: the InCHIANTI study. Rejuvenation Res. 2010;13:3-11.

59. Bautmans I, Njemini R, Lambert M, Demanet C, Mets T. Circulating acute phase mediators and skeletal muscle performance in hospitalized geriatric patients. J Gerontol. 2005;60A:361-7.

60. Leng SX, Xue QL, Tian J, Walston JD, Fried LP. Inflammation and frailty in older women. J Am Geriatr Soc. 2007;55:864-71.

61. Miller RR, Cappola AR, Shardell MD, Hawkes WG, Yu-Yahiro JA, Hebel JR, Magaziner J. Persistent changes in interleukin- 6 and lower extremity function following hip fracture. J Gerontol A Biol Sci Med Sci. 2006;61:1053-8.

62. Tsujinaka T, Fujita J, Ebisui C, Yano M, Kominami E, Suzuki K, Tanaka K, Katsume A, Ohsugi Y, Shiozaki H, Monden M. Interleukin 6 receptor antibody inhibits muscle atrophy and modulates proteolytic systems in interleukin 6 transgenic mice. J Clin Invest. 1996;97:244-9.

63. Zhang L, Du J, Hu Z, Han G, Delafontaine P, Garcia G, Mitch WE. IL-6 and serum amyloid A synergy mediates angiotensin Il-induced muscle wasting J Am Soc Nephrol. 2009;20:604-12.

64. Fischer CP. Interleukin-6 in acute exercise and training: what is the biological relevance? Exerc Immunol Rev. 2006;12:6-33.

65. Trendelenburg AU, Meyer A, Jacobi C, Feige JN, Glass DJ. TAK-1/p38/nNFkB signaling inhibits myoblast differentiation by increasing levels of Activin A. Skelet Muscle. 2012:2:3.
66. Kim TN, Park MS, Lim Kl, Choi HY, Yang SJ, Yoo HJ, Kang HJ, Song W, Choi $\mathrm{H}$, Baik SH, Choi DS, Choi KM. Relationships between sarcopenic obesity and insulin resistance, inflammation, and vitamin D status: the Korean Sarcopenic Obesity Study. Clin Endocrinol (Oxf). 2013;78:525-32.

\section{Submit your next manuscript to BioMed Central and we will help you at every step:}

- We accept pre-submission inquiries

- Our selector tool helps you to find the most relevant journal

- We provide round the clock customer support

- Convenient online submission

- Thorough peer review

- Inclusion in PubMed and all major indexing services

- Maximum visibility for your research

Submit your manuscript at www.biomedcentral.com/submit
Biomed Central 